\title{
Lessons from Australian Water Reforms: Indigenous and Environmental Values in Market-Based Water Regulation
}

\author{
Elizabeth Macpherson, Erin O’Donnell, Lee Godden and Lily O'Neill
}

\begin{abstract}
The Australian model of water governance is considered one of the most effective, efficient and resilient approaches to designing and implementing water governance. In place since the early 1990s, the Australian approach is a hybrid governance system involving collaborative planning of water resources together with market mechanisms and statutory regulation. However, in implementing the model, successive reforms have yet to completely redress the historical exclusion of Aboriginal peoples from water law frameworks, and have struggled to account for the needs of a healthy and sustainable aquatic environment. In this chapter we examine the trajectory of water law and policy reform in Australia, including two of the most recent developments: the push to intensify water development in the northern Australian White Paper and the collaborative planning approach set in the Water for Victoria policy. Our study of the incremental and evolving Australian water law reforms highlights the difficulty of ensuring fairness in the operation of hybrid governance systems for water regulation, and reveals important lessons for international policy-makers embarking on and implementing water reforms in their
\end{abstract}

The authors thank Cameron Holley and Darren Sinclair for organisation of an excellent colloquium that stimulated the initial research. Authors acknowledge assistance provided by CCIF grant 501319GL, The University of Melbourne. The authors' views are their own.

E. Macpherson ( $\square)$

School of Law, University of Canterbury, Christchurch, New Zealand

e-mail: elizabeth.macpherson@ canterbury.ac.nz

E. O'Donnell · L. Godden · L. O’Neill

Centre for Resources, Energy and Environmental Law, Melbourne Law School (CREEL),

Melbourne, Australia

e-mail: erin.odonnell@unimelb.edu.au

L. Godden

e-mail: lcgodden@unimelb.edu.au

L. O'Neill

e-mail: lily.oneill@unimelb.edu.au

C. Holley and D. Sinclair (eds.), Reforming Water Law and Governance,

https://doi.org/10.1007/978-981-10-8977-0_10 
own jurisdictions. From its inception, strategic planning for innovative water law reform must be supported by meaningful engagement with Indigenous peoples, and embed Indigenous and environmental values and rights in water planning and governance.

\section{Introduction}

The Australian approach to water law and governance has been characterised by innovative change that reflects extensive reforms to water law, policy and institutional practice. Initiated in 1994, expanded in the National Water Initiative in 2004 and culminating in the federal Water Act 2007 (Cth), the reforms sought to integrate strategic management objectives through water planning and responded to the environmental effects of over-allocation in the Murray-Darling Basin. The result is a hybrid governance system of collaborative planning of water resources together with market mechanisms and statutory regulation that provides a robust model for potential application in many countries facing water over-allocation across multiple jurisdictions, periodic drought and water scarcity.

The model that developed in Australia is recognised globally as being effective, efficient and resilient in its design and implementation of water governance (Garrick and O'Donnell 2015; Grafton et al. 2011). Yet these far-reaching reforms around water planning and allocation also largely failed to address Indigenous peoples' interests until relatively recently. Sophisticated Indigenous water resource management systems were displaced by the colonisers who introduced the British common law system of riparian water rights, allowing the unregulated use of adjacent water sources by settler landholders. Australian jurisdictions are now experimenting with a range of policy and legal measures that are aimed at providing a more inclusive and equitable platform for Aboriginal peoples and Torres Strait Islanders to engage in water law and governance. Similar experimentation is occurring in other countries, including in Latin America and New Zealand (Ruru 2013; Macpherson 2017), as Indigenous communities seek a stronger voice in water management and assert claims to water rights based on traditional historical associations with water. There is also a strong impetus for water law and governance to respond to human rights imperatives.

This chapter provides an analysis of Australian water law reforms to inform the growing transnational interest in environmental water policy and Indigenous rights to water. It details the poor historical environmental management that lead to over-allocation, and then the environmental flow regimes that were devised in order to protect environmental values in river systems, some using market mechanisms in the interests of the environment (Ison and Wallis 2011). The chapter also details developments such as Indigenous strategic reserves and cultural flows provided for in water planning - water entitlements or shares which are set aside or held by Indigenous people to improve spiritual, cultural, social and environmental conditions, but usually fall short of commercial rights-intended to provide an 
'equitable' share of water resources for indigenous use (Jackson and Barber 2013). There is evidence of similar mechanisms being adopted in other places: including in South American countries, like Chile (O'Donnell and Macpherson 2013). Yet, the Australian experience highlights the difficulty of ensuring fairness in the operation of hybrid governance systems for water regulation; seen particularly in the failure to redress historical and current exclusion of Aboriginal peoples' rights to water, and the continuing task of meeting the needs of a healthy and sustainable aquatic environment. Both of these pose challenges for the ongoing stability and integrity of the Australian model (Lindsay this volume).

The study of evolving Australian water law reforms in this chapter therefore reveals important lessons for international policy-makers embarking on and implementing water law reforms in their own jurisdictions; around the need to appreciate and plan for indigenous and environmental values in the design phase. We examine the trajectory of water law and policy reform in Australia, including the latest push for water development in the northern Australian White Paper, and the direction set in the recent Water for Victoria plan. We argue that strategic planning for innovative reform must be supported by meaningful and constructive engagement with Indigenous peoples ${ }^{1}$ in planning and implementation, and embed environmental and Indigenous values in water governance.

\section{Water Governance in the Driest Continent}

Australia has an unenviable status as the world's driest continent supporting a permanent population (Cullen et al. 2002). Much of Australia's inland area receives less than 500 millimetres of rainfall annually, exacerbated by high evaporation rates, while the coastal fringe has moderate rainfall (Australian Government Bureau of Meteorology 2017). Many of Australia's 246 river basins do not have permanent flow regimes but are marked by periods of intermittent flow. Australia is heavily dependent upon groundwater with a large aquifer system, the Great Artesian Basin, supplying water for inland uses (Tan and Quiggin 2004). Australia also experiences cycles of drought and severe flooding and geographic and seasonal distribution of rainfall varies greatly (Australian Government Bureau of Meteorology 2017).

Indigenous exclusion from water law frameworks has its origins in Australia's colonisation from 1788. Until 1992, the law accepted that the British Crown assumed sovereignty over Australia because Aboriginal people were 'without laws, without a sovereign and primitive in their social organization' (Mabo v Queensland [No 2] (1992) 175 CLR 1, 36 ('Mabo')). Across the continent, British colonisation resulted in the decimation of Aboriginal populations through murder, disease and

\footnotetext{
${ }^{1}$ The term 'Indigenous people' refers to both Aboriginal and Torres Strait Islander communities. As this discussion is focused on mainland Australia, this Chapter uses "Aboriginal peoples" in relation to the relevant communities affected, and 'Indigenous' in relation to a broader discussion of water rights for Australian Indigenous people.
} 
starvation (McHugh 2011, p. 1). The landmark Australian High Court decision in Mabo found that Aboriginal and Torres Strait Islander rights to land and water survived the acquisition of sovereignty by the British Crown, and, in certain circumstances, could be recognised by the Australian common law. 'Native title' under the Native Title Act 1993 (Cth) recognises the rights as the communal, group or individual rights and interests in the land and waters of Aboriginal or Torres Strait Islander people. Proof of the rights requires that claimants demonstrate that they are a society that has continued its connection to those lands and waters since pre-sovereign times according to their traditional laws and customs (Native Title Act 1993 (Cth) s 223; Mabo pp. 59-60; Tehan 2003; Strelein 2009).

Human settlement of the driest continent is now concentrated in the south-east (and parts of the south-west), including major urban areas and agricultural hinterlands (Australian Government Bureau of Statistics 2012). The north is less intensely settled, other than mining and scattered agricultural developments. Northern Australia includes a higher percentage of Aboriginal land; including tenures held pursuant to statutory land grants and native title (National Native Title Tribunal 2016).

The contrast in water conditions between different geographic regions in Australia has led to land characterisation as either part of the 'dry south' or the 'wet north.' Schemes have repeatedly been devised to develop the 'wasted' water resources of the north (Head 1999, p. 153), both for northern irrigated agricultural expansion and transfers via pipeline to the south, where agriculture was already firmly established (Gibbs 2009, p. 2968). There have been parallel debates about whether a lack of water in inland areas would pose an ultimate limit to settlement (Gibbs 2009, pp. 2964-2969).

By the mid-twentieth century commentators began to argue that irrigated agriculture in Australia, particularly in northern regions, was not economically 'efficient' (Davidson 1969). Davidson, for example, argued that the damming of the Ord River in Western Australia-first mooted in the early twentieth century, and achieved at astronomical cost in 1972 with the main dam creating Lake Argylewas a waste of government resources. Agricultural expansion north of the Tropic of Capricorn was not economically rational, Davidson argued, due to harsh seasonal conditions, lack of labour, distance from markets, pests, and inappropriate soils. Instead, money should be channeled into dry-land agricultural innovation (Davidson 1965).

However, the need to develop the land, and avoid land and water going to waste has been a key theme in Australian policy debates around water governance (Head 1999, p. 153). Such an approach rested, Head argues, on colonial views of 'the empty landscape, the invisible Aborigine, and the idealization of agricultural land use' (Head 1999, p. 141). These ideas continue to inform plans to open up new areas of Australia to development, despite the increasing attention given to Aboriginal and environmental issues, and have been 'at least as powerful in driving the process as have any rational or quantitative assessments' (Head 1999, p. 142).

A commitment to irrigation has placed many Australian rivers under increasing pressure, especially in the southern parts of the continent. Irrigation dominates the 
consumptive use of water within Australia (Australian Government Bureau of Statistics 2013), a high proportion of which occurs in the Murray-Darling Basin. While only $10 \%$ of the Basin is formally categorised as 'over-allocated', the entire Murray-Darling Basin might be considered over-allocated where there is insufficient environmental water to deliver sustainability and protect ecological functions (Connell 2007). A large number of Australia's other catchments and ground water supplies have allocations exceeding available sustainable flow, and there are ongoing attempts to address these problems.

Water governance has inevitable social, as well as natural, implications, and 'uneven power relations' influence social access to water rights (Jackson and Barber 2016). The commitment to irrigated agriculture, dominant in public discourse on water governance since colonisation, and the impetus to open 'waste' lands up to development, has also ignored Indigenous peoples, and the uses they have made of water since long before the acquisition of sovereignty pursuant to sophisticated water access rights (Jackson and Langton 2011, p. 109). The way in which law has enabled and responded to these challenges of water governance in Australia is considered in the following sections.

\section{Legal Frameworks Enabling Water Governance in Australia}

\subsection{Early Approaches: Common Law Riparian Rights and State-Based Statutes}

The need for water to support productive land development pervaded early legal frameworks for water governance in Australia. Until the late nineteenth century the common law riparian doctrine provided for rights to water as derivate of property in land (Gardner et al. 2009). A landholder, by virtue of its title, held the right to take and use water on or adjacent to its land. Water that did not flow in a defined river channel was exploitable by a landowner without restriction. Thus, ground and surface waters - very significant parts of the total flow volume of many Australian drainage basins - could be harvested without limit. The common law favoured user rights (Tan 2002, p. 15), but the limitations of this model became apparent in the water-scarce southern and interior areas of the Australian mainland, prompting a move to a different regulatory framework (Tan 2002, p. 16). After severe droughts in the 1880s (Evans and Howsam 2005), Australians began to demand public 'responsibility' for water governance (Powell 1989, pp. 100-104). Towards the turn of the century, several Australian states vested the right to the use and flow of surface and ground water resources in the Crown, and implemented a system of water licences and concessions to authorise the 'consumptive use' of water, focused upon irrigated agriculture. 
River basins became the key focus of the new state-based water law frameworks, to support irrigated agriculture via tightly managed hydrological regimes as a 'tenet of productivism' (Molle 2009, p. 486). Water infrastructure was seen as key to supporting the new approach (Musgrave 2008, p. 35), and extensive public funding was poured into irrigation schemes in the early-twentieth century, including those in the Murray-Darling Basin, to irrigate large areas of dry inland within a worldview of nation-building (Wooding 2009, p. 58). However, the environmental aspects of water attracted little emphasis, and by the early 1980s significant and sustained concerns were raised about impacts on water quality and quantity (Musgrave 2008, p. 39). The legal and institutional structures built around river basins, dams and irrigated agriculture began to rupture, triggering major water law reform.

Moreover, the productivist approach to early water governance in Australia completely ignored the relationships Indigenous Australians had with water resources since long before colonisation (Jackson and Barber 2016). Neither the British Crown nor subsequent Australian governments acknowledged that Indigenous Australians held state-recognised titles with respect to land or resources until the late twentieth century after the introduction of state-based land rights legislation from the 1970s and High Court decision in Mabo in 1992, although some areas of lands were specifically reserved for Aboriginal use. A nexus linking water use to land holding as a basis for agricultural development applied during the same period (Council of Australian Governments 1994), meaning that Indigenous groups, who typically did not hold Torrens (registered) land titles, did not enjoy access to statutory water entitlements, and therefore could not lawfully make use of water on or adjacent to their traditional territories.

\subsection{Introducing the Hybrid Model: Major Water Reforms of the Late Twentieth Century}

By the 1980s, there was increasing pressure on Australian governments to react decisively to intensifying environmental degradation in the Murray-Darling Basin, prompting nation-wide, comprehensive water reform (Department of the Environment and Heritage 2004). At the same time concepts of sustainability and integrated catchment management were introduced to state-based water legislation, including the Water Act 1989 (Vic) (s 1(b)); Water Management Act 2000 (NSW) (s 3); Water Act 2000 (Qld) (s 10(1)) and Natural Resources Management Act 2004 (SA) (s 7). In 1994 the Council of Australian Governments (COAG) agreed to cap water entitlements (finalised in the Murray-Darling Basin in 1997), improve transparency of water pricing, separate water from land and establish property rights to water, and allocate water to the environment, as part of a broader productivity-based policy reform agenda (Australian Government National Water Commission 2011). 
As Australia has a federal system of government there is inevitable overlap between governments in managing water, with considerable tension between jurisdictions. Water regulation has, historically been the responsibility of Australian states and territories. However, a series of high-profile environmental cases established that the Commonwealth Government could use 'indirect' constitutional legislative heads of power to support environmental legislation with respect to natural resources (Crawford 1991). The National Water Initiative was agreed by COAG in 2004, formalising the new approach to water governance and linking state achievement of water reform goals to the receipt of Commonwealth funding. The Initiative committed Australian states to complete the separation of water rights from land; facilitate water trading; set aside legally protected water for the environment; and return over-allocated systems to an environmentally sustainable level (Council of Australian Governments 2004).

The Commonwealth Government progressively assumed a stronger role in water management at the end of the twentieth century under the COAG reforms and in response to major droughts in south-eastern Australia from 1997 to 2009 that significantly reduced water allocations for irrigation and urban water use (State of Victoria 2009, p. 16). The introduction of the Water Act 2007 (Cth), together with a $\$ 10$ billion water plan to save the Murray-Darling Basin, was premised upon the states referring constitutional powers to the Commonwealth, enabling it to pass its own legislation (confirmed in Sects. 9 and 9A of the Water Act). For the first time, the Commonwealth Government had specific water management responsibilities. The reforms introduced new institutions, in the form of the Murray-Darling Basin Authority and the Commonwealth Environmental Water Holder, a sustainable diversion limit on water extraction under the Murray-Darling Basin Plan 2012 (Cth), and significant investment in water recovery for the environment, via purchase programs and investment in water efficiency (Department of Sustainability, Environment, Water, Population and Communities 2011).

After these reforms, together with emblematic changes to the nature of water access entitlements and their unbundling from land titles and transferability in markets, the Australian approach to water governance was dominated by strategic water planning at the catchment level. 'Water planning' is an attempt to match water supplies and water demands, both present and future, so that water resources are managed in a reliable and environmentally sustainable manner, dependent on assessment of the current and future availability and use of water and community stakeholder consultation (Council of Australian Governments 2010). Under the Guidelines for the National Water Initiative environmental flows must have the same level of legislative protection as consumptive water use (Council of Australian Governments 2010, pp. 32-33), while recognising the 'significant' economic value of water to irrigated agriculture, among other water users (Council of Australian Governments 2010 p. 18).

While the COAG reform process was gaining momentum in the early 1990s, Australia was also beginning to recognise Indigenous land rights including, notably, with the recognition of native title in the Mabo decision and subsequent Native Title Act. However, because water rights were unbundled from landholding as part of the 
first stage of the COAG reforms, those Indigenous landholders that acquired land rights, for example in the native title process, would not, as a matter of water law, acquire the right to use water on those lands (Macpherson 2016). This can be contrasted to the situation prior to reforms where the grant of land would have entailed rights to water. Further, because after the COAG reforms rights to use water could be acquired independent of land ownership, third parties could obtain rights to use water on areas over which, for example, there may be recognised native title. Accordingly, if Indigenous water rights are to be provided for, they require specific protections.

The National Water Initiative did acknowledge Indigenous interests and required water plans to take account, at least, of native title rights to water (Council of Australian Governments 2004, [53]). However, it failed to make substantive provision for Indigenous water rights or to effectively engage Indigenous peoples. Most agitation for Indigenous water rights has occurred in subsequent years.

The non-binding, policy character of the Initiative meant that few measures emerged to provide specific water-holding entitlements for Indigenous Australians. It provided that Indigenous peoples' water needs should be taken into account in water planning processes, in the form of water allocations for 'traditional cultural purposes' (Council of Australian Governments 2004, [28]-[34], [59]); to maintain culturally important ecosystems. Thus emerged the concept of 'cultural flows' in the Murray-Darling Basin (Murray Lower Darling Rivers Indigenous Nations and Northern Murray-Darling Basin Aboriginal Nations 2007), for which water should be allocated under either environmental regimes or through a non-tradeable environmental and public benefit water access entitlement (Council of Australian Governments 2004, p. 32). Variations of this concept have been taken up by some state government and local water authorities who appear increasingly keen to incorporate Indigenous water values into water planning. For example, there is a requirement under the Murray Darling Basin plan for consultaion with Aboriginal groups to this effect. The effectiveness of these schemes is yet to be gauged in many instances.

The focus of Australian water planning on Indigenous cultural water values rather than commercial water rights implicitly relies on assigning responsibility to the native title model for attaining holistic Indigenous water rights. The native title process as noted has, to date, failed to recognise a specific right to use water for commercial purposes (Strelein 2009; Australian Law Reform Commission 2015, Chap. 8). Since the litigation culminating in the 2013 High Court decision of Akiba v Commonwealth (2013) 250 CLR 209 some commentators have predicted that Australian native title jurisprudence will evolve to recognise a right to use water for any (including commercial) purpose (O’Donnell 2011). However, Akiba has not been followed with a decision on water and subsequent cases frame 'commercial water rights' in a particular limited sense, contemplating trade in or sale of resources themselves rather that the use of water for associated commercial activities (BP v Western Australia [2014] FCA 715; Western Australia v Willis [2015] FCAFC 186).

Where Indigenous water users require water for commercial purposes, the Initiative contemplates that these entitlements may be acquired through market 
mechanisms, such as water trade and/or direct purchases of water entitlements and licences, the cost of which could be partially borne by governments if they so choose (Council of Australian Governments 2004, p. 32). However, little has been done to provide Indigenous people with commercial water rights until now and those mechanisms that have been introduced, such as Aboriginal access licences under the New South Wales legislation, have enjoyed little uptake (Altman and Arthur 2009, p. 9). Possibly the most ambitious Indigenous water initiatives are 'strategic reserves' of water entitlements (some models include reservations for future Indigenous economic development opportunities) contemplated under certain water plans in parts of northern Australia, although recent governments have shied away from the approach (Stewart 2013). The result is an ongoing discrepancy in Indigenous land and water holdings in Australia, by which Indigenous-held 'water access entitlements' are estimated at only $0.01 \%$ of total Australian water allocations (Jackson and Langton 2011), despite Indigenous land now making up more than $30 \%$ of the Australian continent (Altman and Markham 2015). In light of these stark statistics, and increasing calls from Indigenous groups for greater water equity, the recent developments in the Australian water reform story discussed below place more emphasis on the need to allocate water entitlements to Indigenous peoples from the consumptive pool, in addition to safeguarding environmental (and cultural) flows (Jackson and Barber 2013, 2016).

\subsection{Indigenous and Environmental Values in Recent Water Policies}

Water planning continues to be of immense importance in Australian water allocation and governance. Water policy frameworks have been revisited recently in both northern and southern regions. In northern Australia, where water resources have historically been viewed as 'underexploited', policy frameworks continue to emphasise productive land potential through intensifying irrigated agriculture, with less emphasis on environmental or cultural water values. Perhaps reflecting the more progressive political tendencies in the south, (but also in response to distinct perceived hydrological conditions), the southern approach places more importance on restroration of environmental water and indigenous rights, including the use of market mechanisms. However, whether the more progressive southern policy objectives are translated into statutory or policy change is yet to be seen.

\subsubsection{Our North, Our Future}

The importance of water for productive land use is emphasised in the latest iteration of the Commonwealth Government's plans to open up northern Australian regions of Queensland, Northern Territory and Western Australia to development: Our 
North, Our Future: White Paper on Developing Northern Australia (Australian Government 2015). The White Paper encourages increasing population and bolstering the northern economy by promoting fisheries and agriculture, cutting red tape, increasing business links with Asia, and promoting tropical medicine. In relation to water infrastructure, it provides (Australian Government 2015, p. 40):

Northern development depends on water. Up to 17 million hectares of land in the north have soils which are potentially suitable for agriculture, but there is only water sufficient to irrigate about one tenth of that area. Building the right water infrastructure in the right place will be crucial to realise the full potential of the north. Both surface and ground water in northern Australia serves a variety of functions, including cultural and spiritual use by Indigenous communities. River flows and groundwater are vital for supporting natural environments as well as other productive uses.

In order to extract maximum productive potential from northern water resources $\$ 200$ million will be set aside under the plan for water infrastructure, identifying irrigation and damming potential in river systems across Queensland, the Northern Territory and Western Australia, as well as opportunities to use groundwater in the Western Australian Pilbara region (Australian Government 2015, pp. 43-44). The plan also provides for economic feasibility studies for dams and other potential water infrastructure across northern Australia (18). Thus far, water markets have not been as widely established in northern Australia as in the south-east. The northern approach continues the Australian preference for increased use of market tools, promising the development of 'secure and tradeable water rights as part of a new National Water Infrastructure Development Fund'.

This latest policy approach to developing northern Australia is a continuation of the early engineering approach to water regulation (Crase et al. 2009, p. 446), which has paid insufficient heed to environmental or cultural factors (Turville et al. 2015, p. 2). Turville, Cullen and Tan suggest that the original damming of the Ord River, earmarked for extension in the White Paper, involved 'scant regard' for either Aboriginal communities or the environment and was technically deficient (Turville et al. 2015, pp. 1-2). Jackson and Barber note how the original Ord development 'fundamentally altered the existing indigenous water scape' in the region, with floodwaters displacing indigenous people and cultural sites (Jackson and Barber). Concerns continue to be expressed about the environmental impacts of expanded water infrastructure in northern Australia (Feuvre et al. 2016, p. 176), although these attract little consideration in the White Paper (O'Donnell and Hart 2016).

Given the large Indigenous populations and landholdings in northern Australia, the White Paper would be expected to address Indigenous water values and consultation requirements. The paper does reference the need to consult traditional owners, as well as emphasising the importance of Aboriginal-run projects, including Indigenous ranger programs (Australian Government 2015). However, it continues, as has been the historical practice in northern Australia, to place Indigenous concerns within the broader quest for land development. Joe Morrison of the Northern Land Council, a significant northern Aboriginal land and political organisation, explains (Morrison 2015a): 
Ever since the north was settled - by conquest, not by consent - there have been a cascade of reports which have purported to map various El Dorados, just waiting to be discovered and developed by men of vision... These are not empty lands... Aboriginal people are not afraid of development. We want development, but we want it to be ethical.

The White Paper proposes that Aboriginal landholders work their land through irrigated agriculture, in the interests of long-term economic independence (Australian Government 2015):

The Commonwealth Government supports northern jurisdictions taking actions that support Indigenous Australians to derive greater economic benefits from water on Indigenous land. Water can provide opportunities for Indigenous Australians in diverse areas such as aquaculture, nature based tourism and intensive horticulture. Access to water can also provide an opportunity to participate in water markets, where they exist.

This focus on productive land potential in the north, as opposed to resource conservation, builds on other Commonwealth discussion papers that underscore the need for commercial water rights for Aboriginal economic development (Australian Government 2012, pp. 1-2). Yet, a question remains as to whether this productivist approach represents the views of northern Indigenous people. The Northern Land Council, for example, suggests that it has not been adequately consulted in relation to the White Paper, and insufficiently engaged in water planning more generally (Morrison 2015b).

\subsubsection{Water for Victoria}

In the south-eastern state of Victoria, the demographic and geographic profile is much different, being densely settled and intensively cultivated. Victoria released Australia's newest strategic planning document for water, the Water for Victoria plan, in late 2016, as a 'long-term direction' for the governance of Victorian water resources. The themes of the plan prominently include both environmental and Indigenous aspects, including waterway and catchment health and climate change, and recognising and managing Aboriginal values. These aspects, however, are to be provided for within a framework that utilises the 'water grid' and markets as effective governance tools (State of Victoria 2016, p. 140):

Victoria's water markets allow farmers, the Victorian Environmental Water Holder and water corporations to buy and sell water entitlements and seasonal allocations, so they can manage their own risk according to their willingness to pay. The water markets allow us to share water security benefits in ways that are equitable, responsive and transparent.

Regulation also plays a key role in Victoria, setting rules and standards for the efficient, and equitable, functioning of water markets (State of Victoria 2016, p. 148). The plan encourages greater regulation to ensure accurate information and transparency for effective pricing.

In terms of environmental water values, the plan goes little further than more innovative reforms by previous governments, notably, the creation of the Victorian Environmental Water Holder in 2010 (O’Donnell and Macpherson 2013), which, 
similar to the Commonwealth Environmental Water Holder, manages a portfolio of water allocations and flows in the interests of the environment within the market framework (O'Donnell 2012). The plan signals further investment in waterway health, integrated catchment management and protections of beneficial uses (State of Victoria 2016, p. 50). Also, there is to be further investment in environmental watering, acknowledging the impact of climate change, and increased monitoring and research (State of Victoria 2016, p. 54).

In terms of Aboriginal water values, the Water for Victoria plan does appear to break new ground, probably in response to the historical dearth of Indigenous water protections in Victoria and increasing lobbying by Indigenous groups in the context of a commitment to treaty negotiations by the state government. The 2016-2017 Victorian Budget committed \$4.7 million to embedding Aboriginal values and knowledge in Victorian water management. The plan highlights a need for greater Indigenous involvement and consultation in water planning, and incorporating traditional knowledge via an 'Aboriginal Water Reference Group', with representation from Traditional Owners with knowledge of water management (State of Victoria 2016, p. 98).

The plan even suggests that in the future Aboriginal Victorians may be provided with water access for economic development purposes, facilitating 'economic self-determination' via water-related Aboriginal enterprises (State of Victoria 2016, p. 98). This prospect has not been raised before in the Victorian context, including under Victoria's statutory regime for traditional owner settlements in lieu of native title, which apply only to 'traditional purposes' (Traditional Owner Settlement Act 2010 (Vic) s 79). Remarkably, the plan refers to a potential to reallocate water access entitlements to traditional owners, including by acquiring water entitlements from water corporations in areas where this is allowable within sustainable limits, investing in water savings projects that create new entitlements, and buying water in water markets in areas where entitlements or use is capped at sustainable limits (State of Victoria 2016, p. 106). However, the aims of the plan are vague and non-committal; suggesting that any real reform is many years away, if to eventuate at all. The plan advocates working with traditional owners to develop a 'roadmap for access to water for economic development', to 'consider opportunities' for Aboriginal access to water for economic development purposes, and to 'notify traditional owners' when opportunities for access arise (State of Victoria 2016, p. 106). Beyond the rhetoric, there are no concrete requirements in Water for Victoria to reform water legislation or create specific legal water entitlements for Indigenous people in catchment-level plans.

The absence of effective policy directions reflects the competitiveness and political sensitivity of water distribution in Victoria, and the potential cost involved in water reallocation (Jackson and Langton 2011). The legal position is that the Victorian approach continues to 'compartmentalise' Indigenous water values as heritage values (Jackson 2010), principally via the concept of 'cultural flows'. Typically, such flows do not draw upon the pool of consumptive water allocations. Rather, the plan contemplates that Indigenous groups are to share benefits with environmental flows and programmes; although the groups are to be directly 
involved in water planning and the identification of cultural values in waterways. Thus, this latest iteration of Australian water policy, aside from highlighting a need for open and meaningful consultation with Indigenous groups, demonstrates the iterative and lengthy process of community-focused water reforms, and the tradeoffs implicit in safeguarding Indigenous and environmental values in competitive water markets.

\section{Lessons for an International Audience}

\subsection{Including Indigenous Peoples in Water Governance}

The Australian experience with water reform highlights the importance of strategic planning to accommodate Indigenous interests within hybrid governance systems for water resource management that rely on a combination of government regulation and water markets. The initial Murray-Darling Basin water law reform process, in which Indigenous water rights were barely considered, demonstrates that detailed water resource assessments and plans, and the design of water entitlements, need to include not only technical assessments of water allocation based on hydrology and ecology, but also community values, especially the cultural values of Indigenous peoples. Water resource assessments and planning are tools widely used in many countries. Thus, measures designed to include Indigenous peoples' interests in water potentially have wide application.

Internationally, there is growing emphasis on free, prior and informed consent and the need for equitable and transparent approaches to engagement with Indigenous communities. These principles have pertinence for the water law reform process in many countries. Undoubtedly, the first step in adequately accommodating Indigenous values is meaningful consultation; in order for non-Indigenous water planners to better understand Indigenous water perspectives and, as emphasised by Lindsay in chapter 10, to seek the consent of Indigenous people to water developments that affect them (Lindsay this volume). The introduction of water reforms in Australia in the early 1990s largely overlooked Indigenous water rights and there was minimal consultation. Recent iterations of the Australian reform measures do emphasise free, prior and informed consent, and acknowledge the importance of incorporating indigenous values in water governance, although what may be encompassed by 'meaningful engagement' with Aboriginal peoples is still being tested.

The Water for Victoria plan is indicative of emerging strategies that seek to facilitate consultation with and the participation of Indigenous people in water governance, in an effort to better embed Aboriginal values and knowledge in water management. The Victorian plan encourages greater Indigenous involvement in water planning, and the incorporation of traditional knowledge via an 'Aboriginal Water Reference Group', with representation from traditional owners with 
knowledge of water management (State of Victoria 2016, p. 98). Whether this non-binding policy document does in fact lead to meaningful consultation, in which Aboriginal Victorians are actually able to influence the reform of water law and policy, is yet to be seen.

Moreover, until now most legal and policy debates about Indigenous water rights in Australia, in reliance on the native title model, have presented Indigenous interests as having a 'traditional-cultural' character (O'Bryan 2012; Lane 2000; Australian Human Rights Commission 2009). In situations where some form of 'entitlement' is contemplated, the cultural flow model has predominated (Godden and Gunther 2009, p. 244). The cultural flows model as a first step can play a useful role in promoting the inclusion of Indigenous peoples in water governance processes with governments and Indigenous representative groups recognising their significance in this regard (Murray Lower Darling Rivers 2007). Current legal mechanisms providing for Indigenous water rights in Australia, though, do not effectively support Aboriginal water use for commercial purposes, focusing instead on cultural and environmental interests. These important values merit protection, but a broader perspective that takes into account the history of exclusion from culturally appropriate economic opportunities is required (Macpherson 2016). Arguably, a limitation of the concept of cultural flows is that such interests have tended to be narrowly realised via in-stream protections, similar to the environmental flows model, although the concept itself does contemplatate commercial water use. The cultural flows model may not be sufficient to achieve substantive Aboriginal outcomes unless water law frameworks also set aside a share of the consumptive pool for Indigenous users or otherwise provide for water for cultural economy purposes.

Indeed, the protection of customary rights to water and/or cultural flows finds resonance other jurisdictions, such as New Zealand, which has moved much further along the spectrum in providing robust legal and institutional protections for indigenous peoples 'cultural' rights to water (see e.g. Te Awa Tupua (Whanganui River Claims Settlement) Act 2017 (NZ)). The Australian experience affirms the importance of protecting traditional cultural flows but also acknowledges the need for more holistic approaches that can encompass commercial utilisation of water.

Despite significant legal barriers and a lack of formal acceptance, Indigenous communities seek to exercise their management rights over water in accordance with cultural norms (Jackson and Barber 2016). To achieve equity, and consistent with international human rights, Aboriginal peoples' water rights should have the same characteristics as the rights available to non-Indigenous water users since Australia was colonised. Thus, Aboriginal people should be able to choose whether to exercise water rights for cultural or economic development purposes (Jackson and Langton 2011). Australian experience here lags behind international best practice as some jurisdictions have accorded indigenous communities the capacity to exercise water rights for commercial uses and in order to support economic development, notably in Latin America (Macpherson 2017). This much, at least, appears to be contemplated in the White Paper for developing northern Australia and the Water for Victoria policy, both of which reference the potential use of water 
by Indigenous people for commercial purposes. Importantly, if Indigenous interests in water are not factored into planning for water markets, then Aboriginal peoples will again be excluded from their economic benefits.

Furthermore, an important lesson from the Australian experience is to account for Indigenous water interests when designing wider water reforms that encompass market measures. Typically a prerequisite of water market implementation is the 'full' allocation of entitlements within the relevant water system, so some accounting for current and future Indigenous interests is vital. By contrast, in the Murray-Darling Basin in southern Australia there was no provision made in the consumptive pool for Indigenous water use when existing entitlements were 'grandfathered' as water markets were introduced. A critical resulting problem is the expense and difficulty of buying-back entitlements in a fully allocated system if Indigenous water rights are to be contemplated. For this reason, policy approaches that propose to set aside 'strategic indigenous reserves' in water catchments for future allocation to Indigenous peoples in areas where water is still plentiful are a welcome development (Jackson and Barber 2013). Unfortunately, as noted above, there is a tendency to move away from such policy approaches in northern Australia in recent years and the Water for Victoria plan remains little more than aspirational in this regard.

While there is a diversity of views, many Aboriginal communities recognise a need for economic development (including via the exploitation of water resources) as providing employment and long-term viability for their communities, even while, 'they are very determined to protect their country and sacred sites' (Australian Law Reform Commission 2015, p. 54). Collaborative water planning processes must ensure Aboriginal and multiparty confidence in holistic water planning and development outcomes (Jackson et al. 2012, p. 22).

In northern Australia, Indigenous people are an important stakeholder group with respect to any plans for water development (O’Neill et al. 2016). Aboriginal people have significant statutory landholdings together with a growing number of native title determinations. Aboriginal peoples and Torres Strait Islanders are a larger percentage of the population across northern Australia, meaning that their opinions, interests and aspirations may hold more political sway than in the south. Thus, culturally appropriate Aboriginal consultation and inclusion is all the more vital as Aboriginal people are the demographic group most likely to be impacted by water development (Greiner 2000). Notwithstanding, there is less guidance on the role of Indigenous people in developing water reform in the White Paper, which makes scant provision for future consultation. Taking into account economic, social and environmental factors is a stated principle behind any proposed new water infrastructure (Australian Government 2015, p. 51). Exactly how the detail of social impact will be measured or accounted for is uncertain. Previous northern development planning and project implementation failed to consult with Aboriginal people, or to effectively account for social and cultural impacts (Greiner 2000). Consultation and participation processes must be significantly different in any new phases of development if it proceeds. 
In this respect, northern Australian Governments could find a useful model in the extensive consultation process developed for the proposed Kimberley Browse liquefied natural gas (LNG) development. The consultation with Aboriginal peoples in the Kimberley region went well beyond typical public participation processes. In 2006, then Western Australian Premier Alan Carpenter said that the Kimberley Browse development would only go ahead with the support of Kimberley traditional owners and it would be 'a dialogue, not an imposition or a demand' (Western Australian Government 2006, p. 8443c). The initial level of political commitment to obtaining Aboriginal consent was viewed in some quarters as giving Aboriginal people a de facto veto over the Browse development (O'Neill 2014). Whether further expansion of water infrastructure should take place in northern Australia also is likely to be strongly contested. An effective process for engaging Aboriginal peoples is vital, but the broader exclusion of Aboriginal interests from commercial uses of water, in the context of interplay of environmental priorities and Aboriginal interests, must also be addressed. As this overview has identified, there are principles and models in place in Australia that can be drawn upon to ensure more robust consultation and participation with Indigenous communities around their involvement in water governance. Australian water law and policy has long functioned as de facto social and economic policy-now there is a need to be explicit about the extent to which Australian water law and policy will actively provide culturally appropriate opportunities for Indigenous participation in water governance and economic development that is in line with emergent international practice.

\subsection{Embedding Environmental Values}

Australia has been more explicit in its attempts to embed environmental values and outcomes in water governance. Internationally, its models and approaches in the implementation of environmental flows are leading edge (Grafton et al. 2011), although in the face of fierce competition for water, protecting environmental water interests in many Australian jurisdictions remains challenging. Such challenges confirm the importance of strategic planning for environmental water at the early stages of policy design. The experience of the Murray-Darling Basin and the significant levels of effort and funding required to restore overallocated and degraded river systems shows that it is much easier to protect existing environmental flows than to restore these flows in the future (O'Neill et al. 2016). First, it is less complex (procedurally and legally) to implement flow protection mechanisms based on new rights than it is to change the water rights of existing users - and much less expensive (Horne et al. 2017). The protection of environmental flows as part of initial water planning and allocation, however, does require significant upfront investment in understanding water resources, ecology and social and cultural values of the affected area (Pahl-Wostl et al. 2013). 
There are critical insights from the long, costly and as yet unfinished attempts to provide adequate environmental water in the Murray-Darling Basin that should be noted by other jurisdictions contemplating water reforms. Experience in Australia has demonstrated that establishing and maintaining adequate environmental flows to protect both the resource base and the ecological functions of water dependent ecosystems is complex (Connell and Grafton 2011). Environmental flows need to be identified and protected using a range of legal mechanisms with adequate legal security. As a minimum, these mechanisms should include: a cap on water extraction, conditions on dam location and operation, and a minimum flow or environmental water allocation to protect the environment during dry years (Horne et al. 2017).

Other jurisdictions should note that capping water extraction will protect the important high flow events on which the water dependent ecosystems rely. Not only will this facilitate trade, but setting a conservative cap will encourage high value, efficient water uses initially, while also enabling the potential for the cap to be raised in future (if warranted). This cap needs to be expressed as a proportion of the available flow rather than an absolute volume, so that it continues to protect environmental flows during dry years as well as wet years.

Further, dams need to be located where they minimise environmental impacts and, where possible, should be off-stream. One of the critical lessons from the Murray-Darling Basin on-stream dams is that reducing the effect of large on-stream dams on the timing and frequency of flow events is extremely challenging once the dams are in operation (US Army Corps of Engineers and The Nature Conservancy 2011; Richter and Thomas 2007). On-stream dams need to be operated to protect the seasonality, frequency and duration of important flow events.

Climate change and increased water extraction are likely to increase the frequency and duration of droughts and extended dry periods (Steffen 2015). By protecting critical drought refuges, ecosystems will be able to respond and recover when water availability improves once more. Establishing a minimum flow release from on-stream dams, and creating environmental water rights, is an extremely effective mechanism for ensuring that environmental managers have the capacity to respond flexibly in dry periods, and to meet ecological needs efficiently (Horne 2009). The crucial role of groundwater as a critical reserve must also be recognised (Martin 2016).

Finally, environmental water needs to be managed effectively and efficiently to deliver maximum benefit for the available water (Horne et al. 2009, p. 779). Environmental water management depends on interactive partnerships between catchment managers, water resource planners, river and storage operators and the community (Garrick et al. 2011, p. 167; Garrick and O'Donnell 2015). These relationships are complex and governance arrangements need to be addressed at the outset. At the federal level, the Commonwealth Environmental Water Holder operates as the single decision-maker for the use of environmental water rights each year (O’Donnell 2013). A single organisation responsible for implementation helps to streamline decision-making, achieve economies of scale in environmental water 
management, and enhance accountability by having an identifiable decision-maker (O’Donnell 2012, 2013).

Disappointingly, recent Australian water policy pays insufficient attention to environmental water. The northern Australian White Paper is almost completely silent on the issue of environmental flows, beyond the brief acknowledgment of the need for a sustainable limit on extractions. Water for Victoria, promises more investment in environmental water programmes and monitoring but specifies no improvements to existing regimes. The Australian experience shows that embedding environmental values in water governance is not a one-off event, but must be an ongoing process of reflective and responsive reform to learn from and adapt to prior mistakes (O’Donnell and Garrick 2017b).

\section{Conclusion}

Internationally, Australia is regarded as a highly innovative water manager-with much of this credential tied to the extensive law reforms initiated under the National Water Initiative in the Murray-Darling Basin. While internal debates continue about the level of effectiveness of these reforms in achieving long-term sustainability, many valuable lessons may be drawn from the Australian experience. These include that any process for water reform must embed environmental values in water planning, creating legal rights to environmental water to protect existing ecological values, and establishing a system of governance to promote the effective and efficient use of environmental water. Policy developments must be scrutinised for impacts upon Indigenous peoples (and indeed other cultural groups as relevant to the respective jurisdiction), in terms of substantive opportunities for involvement in water planning processes, and inclusion in water entitlement allocations and corresponding economic benefits. Reforms of water law and policy frameworks offer an opportunity for Indigenous peoples, if effectively supported to do so, to be an integral element of any strategic planning for hybrid water governance in the future.

\section{References}

Altman, J. C., \& Arthur, W. S. (2009). Commercial water and indigenous Australians: A scoping study of licence allocations. CAEPR Working Paper No 57/2009, Centre for Aboriginal Economic Policy Research. http://apo.org.au.

Altman, J., \& Markham, F. (2015). Burgeoning indigenous land ownership: Diverse values and strategic potentialities. In S. Brennan et al. (ed.), Native title from mabo to akiba: A vehicle for change and empowerment? The Federation Press.

Australian Government Bureau of Statistics. (2013). Australian Yearbook 2012. Geographic Distribution of the Population. http://www.abs.gov.au/ausstats/abs@.nsf/Lookup/by\% 20Subject/1301.0 2012 Main\%20Features Geographic\%20distribution\%20of\%20the\% 20population $\sim 49$. 
Australian Government. (2012). Position statement: Indigenous access to water resources. National Water Commission. http://www.nwc.gov.au/_data/assets/pdf_file/0009/22869/IndigenousPosition-Statement-June-2012.pdf.

Australian Government. (2015). Our north, our future: White paper on developing Northern Australia. http://northernaustralia.gov.au/files/files/NAWP-FullReport.pdf.

Australian Human Rights Commission. (2009). 2008 Native Title Report. Human Rights and Equal Opportunity Commission. https://www.humanrights.gov.au/our-work/aboriginal-andtorres-strait-islander-social-justice/publications/native-title-report-2008.

Australian Law Reform Commission. (2015). Connection to country: Review of the native title act 1993 (Cth). Report No 126. http://www.alrc.gov.au/publications/alrc126.

Connell, D. (2007). Water politics in the murray-darling basin. Federation Press.

Connell, D., \& Grafton, R. (2011). Basin futures: Water reform in the murray-darling basin. ANU E Press.

Council of Australian Governments. (1994). Report of the Working Group on Water Resource Policy to the Council of Australian Governments. Unpublished.

Council of Australian Governments. (2004). Intergovernmental agreement on a national water initiative. http://www.pc.gov.au/inquiries/current/water-reform/national-water-initiative-agreement-2004.pdf.

Council of Australian Governments. (2010). National water initiative policy and guidelines for water planning management.

Crase, L. R., O'Keefe, S. M., \& Dollery, B. E. (2009). The fluctuating political appeal of water engineering in Australia. Water Alternatives, 2(3), 440-447.

Crawford, J. (1991). The constitution and the environment. Sydney Law Review, 13(1), 11-30.

Cullen, P., Flannery, T., Harding, R., Morton, S.R., Possingham, H.P., Saunders, D.A., Thom, B., Williams, J., Young, M.D., Cosier, P., \& Boully, L. (2002). Blueprint for a living continent: A way forward from the wentworth group of concerned scientists. http://wentworthgroup.org/ 2002/11/blueprint-for-a-living-continent/2002/.

Davidson, B. (1969). Australia wet or dry: The physical and economic limits to the expansion of irrigation. Melbourne University Press.

Davidson, B. (1965). The northern myth: A study of the physical and economic limits to agricultural and pastoral development in tropical Australia. Melbourne University Press.

Department of Sustainability, Environment, Water, Population and Communities. (2011). Water For the Future. http://www.environment.gov.au.

Department of the Environment and Heritage. (2004). Integrated water resource management in Australia: Case studies - murray-darling basin initiative. http://www.environment.gov.au/node/ 24407.

Evans, B., \& Howsam, P. (2005). A critical analysis of the riparian rights of water abstractors in England and wales. Journal of Water Law, 16(3), 90-94.

Feuvre, L., Matthew, C., Dempster, T., Shelley, J. J., \& Swearer, S. E. (2016). Macroecological relationships reveal conservation hotspots and extinction-prone species in Australia's freshwater fishes. Global Ecology and Biogeography, 25, 176-186.

Gardner, A., Richard, B., \& Gray, J. (2009). Water resources law. Chatswood: LexisNexis Butterworths.

Garrick, D., \& O’Donnell, E. (2015). Exploring private roles in environmental watering in Australia and the US. In J. Bennett (ed.) Protecting the environment, privately. World Scientific.

Garrick, D., Lane-Miller, C., \& McCoy, A. L. (2011). Institutional innovations to govern environmental water in the Western United States: Lessons for Australia's murray-darling basin. Economic Papers 30(2):167-184.

Gibbs, L. M. (2009). Just add water: Colonisation, water governance, and the Australian Inland. Environment and Planning A. 41:2964.

Godden, L., \& Gunther, M. (2009). Realising capacity: Indigenous involvement in water law and policy reform in South-Eastern Australia. Journal of Water Law, 20(5/6), 243-253. 
Grafton, R. Q., Libecap, G., McGlennon, S., Landry, C., \& O’Brien, B. (2011). An integrated assessment of water markets: A cross-country comparison. Review of Environmental Economics and Policy, 5(2), 219-239.

Greiner, R. (2000). The northern myth revisited: A resource economics research response to renewed interest in the agricultural development of the kimberley region. In Annual conference of the Australia agricultural and resource economics society, Sydney.

Head, L. (1999). The northern myth revisited? Aborigines, environment and agriculture in the ord river irrigation scheme, stages one and two. Australian Geographer, 30, 141-158.

Horne, A., O'Donnell, E., \& Tharme, R. (2017). Mechanisms for allocating environmental water. In A. Horne, M. Stewardson, A. Webb, M. Acreman, \& B. Richter (Eds.), Water for the environment: from policy and science to implementation and management. Elsevier.

Horne, A., Stewardson, M., Freebairn, J., \& McMahon, T. A. (2009). Using an economic framework to inform management of environmental entitlements. River Research and Applications, 26, 779-795.

Horne, A. (2009). An approach to efficiently managing environmental water allocations. PhD Thesis. University of Melbourne.

Ison, R., \& Wallis, P. (2011). Institutional change in multi-scalar water governance regimes: A case from Victoria, Australia. The Journal of Water Law, 22(3), 85-94.

Jackson, S. (2010). Compartmentalising culture: The articulation and consideration of Indigenous values in water resource management. Australian Geograper, 37(1), 19-31.

Jackson, S., \& Barber, M. (2013). Recognition of indigenous water values in Australia's Northern Territory: Current progress and ongoing challenges for social justice in water planning. Planning Theory \& Practice, 14(4), 435-454.

Jackson, S., \& Barber, M. (2016). Historical and contemporary waterscapes of North Australia: Indigenous attitudes to dams and water diversions. Water History, 8(4), 385-404.

Jackson, S., \& Langton, M. (2011). Trends in the recognition of indigenous water needs in Australian water reform: The limitations of 'cultural' entitlements in achieving water equity. Journal of Water Law, 22, 109-123.

Jackson, S., Tan, P.-L., \& Nolan, S. (2012). Tools to enhance public participation and confidence in the development of the howard east aquifer water plan, northern territory. Journal of Hydrology, 474, 22-28.

Lane, P. (2000). Native title and inland waters. Indigenous Law Bulletin, 4(29), 11.

Macpherson, E. (2016). Commercial indigenous water rights in Australian law: Lessons from Chile. Ph.D Thesis. University of Melbourne.

Macpherson, E. (2017). Beyond recognition: lessons from chile for allocating indigenous water rights in Australia. University of New South Wales Law Journal 40(3).

Martin, P. (2016). Creating the next generation of water governance. Environmental and Planning Law Journal, 33(4), 388-401.

McHugh, P. (2011). Aboriginal societies and the common law: A history of sovereignty. Status and Self-Determination: Oxford University Press.

Molle, F. (2009). River-basin planning and management: The social life of a concept. Geoforum, 40, 484-494.

Morrison, J. (2015). Keynote Speech at garma festival, gulkula. http://www.nlc.org.au/mediareleases/article/keynote-speech-at-garma-festival.

Morrison, J. (2015) Resilient communities and sustainable prosperity-Northern indigenous development (Townsville, 22 July 2015).

Murray Lower Darling Rivers Indigenous Nations and Northern Murray-Darling Basin Aboriginal Nations. (2007). Agreed Definition of Cultural Flows. http://www.mdba.gov.au.

Musgrave, W. (2008). Historical development of water resources in Australia. In L. Crase (ed.), Water policy in Australia: The impact of change and uncertainty, resources for the future.

O'Bryan, K. (2012). The national water initiative and Victoria's legislative implementation of indigenous water rights. Indigenous Law Bulletin, 7(29), 24-27. 
O'Donnell, M. (2011). Indigenous rights in water in Northern Australia. Project 6.2. Northern Australia indigenous land and sea management alliance-tropical rivers and coastal knowledge. Charles Darwin University.

O'Donnell, E. (2012). Institutional reform in environmental water management: The new Victorian Environmental Water Holder. Journal of Water Law, 22, 73-84.

O'Donnell, E., \& Macpherson, E. (2012). Challenges and opportunities for environmental water management in Chile: An Australian perspective. Journal of Water Law, 23(1), 24-36.

O'Donnell, E. (2013). Australia's environmental water holders: Who is managing our environmental water? Australian Environment Review, 28, 508-513.

O'Donnell, E., \& Hart, B. (2016). Damming Northern Australia: We need to learn hard lessons from the south. The Conversation. 10 February.

O’Donnell, E., \& Garrick, D. (2017a). Environmental water organizations and institutional settings. In A. Horne, M. Stewardson, A. Webb, M. Acreman, \& B. Richter (Eds.) water for the environment: From policy and science to implementation and management. Elsevier.

O'Donnell, E., \& Garrick, D. (2017b). Defining success: A multi-criteria approach to guide evaluation and investment. In A. Horne, M. Stewardson, A. Webb, M. Acreman, \& B. Richter (Eds.), Water for the environment: From policy and science to implementation and management. Elsevier.

O’Neill, L., Godden, L., Macpherson, E., \& O’Donnell, E. (2016). Australia, Wet or Dry, North or South: addressing environmental impacts and the exclusion of Aboriginal peoples in northern water development. Environmental and Planning Law Journal, 33(4), 402-417.

O'Neill, L. (2014). The role of state governments in native title negotiations: A tale of two agreements. Australian Indigenous Law Review, 18(2), 29-42.

Pahl-Wostl, C., Arthington, A., Bogardi, J., Bunn, S. E., Hoff, H., Lebel, L., et al. (2013). Environmental flows and water governance: Managing sustainable water uses. Current Opinion in Environmental Sustainability, 5, 341-351.

Powell, J. (1989). Watering the garden state: Water, land and community in Victoria 1834-1988. Allen \& Unwin.

Richter, B. D., \& Thomas, G. A. (2007). Restoring environmental flows by modifying dam operations. Ecology and Society [online] 12(1). http://www.ecologyandsociety.org/vol12/iss1/ art12/.

Ruru, J. (2013). Indigenous restitution in settling water claims: the developing cultural and commercial redress opportunities in Aotearoa, New Zealand. Pacific Rim Law \& Policy Journal, 2, 311-352.

State of Victoria. (2009). Northern region sustainable water strategy. Department of Sustainability and Environment.

State of Victoria. (2016). Water for Victoria. Department of Environment, Land, Water and Planning.

Steffen, W. (2015). Thirsty country: Climate change and drought in Australia. Climate Council of Australia.

Strelein, L. (2009). Compromised jurisprudence: Native title cases since mabo, 2nd edn. Aboriginal Studies Press.

Stewart, P. (2013). Indigenous water reserve policy tap turned off. ABC News (Online). 10 October. http://www.abc.net.au/news/2013-10-09/ntindigenous-water-reserve-policydropped/5012152.

Tan, P. L. (2002). Legal issues relating to water use in land and water in Australia. In Property rights and responsibilities, current Australian thinking. AGPS.

Tan, P.-L., \& Quiggin, J. (2004). Sustainable management of the great artesian basin: An analysis based on law and environmental economics. Australasian Journal of Natural Resources Law and Policy., 9, 255-303.

Tehan, M. (2003). A hope disillusioned, an opportunity lost: reflections on common law native title and ten years of the native title act. Melbourne University Law Review, 27, 523-571.

Turville, A. C., Cullen, S., \& Tan, P.-L. (2015). Planning for the future: integrated water management in the ord river catchment. Water, 41, 80-86. 
US Army Corps of Engineers and The Nature Conservancy. (2011). Sustainable rivers project: improving the health and life of rivers, enhancing economies, benefiting rivers, communities and the nation. US Army Corps of Engineers, The Nature Conservancy.

Western Australian Government. (2006). Parliamentary debates. Legislative Assembly, 21 November. 8443c-8443c. Alan Carpenter, Premier.

Wooding, R. (2009). Populate, parch and panic: Two centuries of dreaming about nation building in Inland Australia. In A. W. Gardner et al (Eds.), Water resources law, LexisNexis Butterworths 57. 